\title{
ANALISIS PERAN MEDIA SOSIAL DALAM PELAKSANAAN PEMBANGUNAN NASIONAL
}

\author{
${ }^{1}$ Novliza Eka Patrisia, ${ }^{2}$ Faizal Anwar, ${ }^{3}$ Hafri Yuliani \\ 1,2,3 Universitas Muhammadiyah Bengkulu, \\ novlizaekap@umb.ac.id
}

Diterima : 01 November 2020; Review : 20 Januari 2021; Direvisi Author : 25 Januari 2021; Terbit : 14 Februari 2021

\begin{abstract}
This paper is the result of analysis and observation that reviews the use of social media in the form of social networks as a medium of communication and information that is very effective to convey problems or aspirations of the community, especially for areas that have not been maximally touched by the media and are not widely known by the public in particular, local officials today. This research was conducted in the city of Bengkulu, with informants are employees of the City Information Service bengkulu as many as 10 people, and the general public a number of 5 people who are users of social media . informant determination techniques using purposive samples, namely selecting and determining informants at the beginning of research, and the selected informant is believed to represent the object studied. This paper aims to describe the characteristics of digital society that uses social media. Then, it illustrates the relationship between social media and national development andillustrates the opportunities and challenges that arise in the digital age. This researchmethod is a descriptive study using qualitative analysis. The results showed that national development will be realized well if a social media in the form of social networks are used by the public well, ethically and justifiably. Therefore, the role of local government is very important in informing the community quickly and accurately.
\end{abstract}

Keywords: Social media, National development, Digital Age, Digital society.

\section{PENDAHULUAN}

Informasi merupakan sesuatu yang mendasar bagi pengetahuan, dan penduduk yang terdidik dan berpengetahuan adalah penduduk yang mengalami pemberdayaan dan oleh karena itu dapat berpartisipasi dalam urusan penduduk, pembangunan sosial, dan kemajuan. Menurut H.A.W. Wijaya (Ubaidillah, 2016) komunikasi adalah tingkah laku perbuatan atau kegiatan penyampaian atau pengoperan lambing-lambang yang mengandung makna atau arti. Atau perbuatan penyampaian suatu gagasan atau informasi dari seseorang kepada orang lain. Atau suatu pemindahan atau penyampaian informasi mengenai pikiran-pikiran dan perasaanperasaan.

Di era digital ini perkembangan teknologi terjadi sebuah evolusi pada teknologi media, sebut saja new media atau orang juga sering menyebutnya media online atau orang lebih akrab lagi menyebutnya dengan istilah internet, media ini tentunya sudah tidak asing lagi di telinga. Media ini juga disebut-sebut sebagai media yang sampai saat ini belum ada yang menandingi pertumbuhan jumlah penggunanya. Negara maju, new media mengalahkan berbagai media yang sebelumnya telah dijadikan sumber 
referensi dalam mendapatkan sebuah informasi. Istilah new media muncul pada akhir abad 20, istilah ini digunakan untuk menyebut media jenis baru yang menggabungkan antara media konvensional dengan media internet. Dalam kurun waktu beberapa tahun belakangan ini new media diramaikan oleh fenomena munculnya situs jejaring sosial, situs ini menyediakan tempat didunia maya untuk membangun suatu komunitas jejaring pertemanan yang dapat diakses oleh semua orang di seluruh dunia.

Kemampuan interaktif ini juga dimiliki oleh jejaring sosial seperti Facebook dan Instagram ini lah, yang membuat media online lebih unggul lagi dibanding media tradisional yang hanya bersifat satu arah dalam menyampaikan pesan komunikasinya. Pada media jejaring sosial seperti Facebook dan Instagram mampu memberikan feedback secara langsung sehingga tercipta komunikasi antar pribadi.

Tulisan ini bertujuan untuk menggambarkan karakteristik masyarakat digital yang menggunakan media sosial. Kemudian, menggambarkan hubungan antara media sosial dan pembangunan nasional serta menggambarkan peluang dan tantangan yang muncul di era digital.

\section{METODOLOGI PENELITIAN}

\section{a. Media Sosial Facebook dan Instagram}

Media baru yang beroperasi dalam jaringan (internet) telah dimanfaatkan dalam setiap sendi kehidupan masyarakat, baik ekonomi, sosial, politik maupun budaya. Dimanfaatkan oleh individu, kelompok maupun institusi dan lembaga negara. Berbicara tentang internet dan media baru khususnya, tidak dapat kita lepaskan dari wujud media baru itu sendiri layaknya sosial media. Salah satu fungsi sosial media "saat ini” adalah fungsi pelayanan publik, dimana sosial media dimanfaatkan sebagai media pelayanan publik oleh institusi maupun lembaga negara (Yuliani et al, 2020).

Facebook dan Instagram begitu cepat beradaptasi dengan perkembangan teknologi yang populer ini merupakan nilai tambah bagi Facebook dan Instagram yang lengkap dengan fitur chatting dan status pengguna aktif menjadi fasilitas yang mampu menghidupkan situs jejaring sosial ini, dengan fitur chatting ini pengguna Facebook dan Instagram dapat berinteraksi dua arah secara langsung dan fitur pengguna aktif adalah untuk mengetahui temanteman yang sedang online. Dengan situs jejaring sosial Facebook dan Instagram beberapa hal yang tidak mampu dilakukan oleh situs jejaring lainya Facebook dan Instagram mampu melakukannya karena Facebook dan Instagram dibekali dengan fitur-fitur canggih dan lebih aman, mulai berbagai informasi, berbagi foto, berbagai video dan banyak lagi hal-hal menarik lainnya. Bahkan para pengguna yang sedang giat dalam melakukan promosi produk dan jasa atau sedang melakukan kegiatan komunikasi pemasaran Facebook dan Instagram menjadi 
sales yang handal dalam membantu pengenalan produk dan jasa yang ditawarkan (Madcoms \& Andi, 2010).

Morissan (2019) menyatakan bahwa media interaktif memungkinkan terjadinya arus informasi timbal balik yang memungkinkan pengguna dapat berpartisipasi dan memodifikasi isi dari informasi pada saat itu juga (real time). Berdasarkan hal tersebut menunjukan bahwa pengguna media komunikasi dalam bentuk jejaring sosial sangatlah tinggi. Sehingga masyarakat perlu di bina dan diberikan penyuluhan bagaimana penggunaan media komunikasi dalam bentuk jejaring sosial yang baik dan beretika, karena hal ini sangat berpengaruh terhadap kemajuan pembangunan nasional Indonesia. Berikut beberapa etika yang harus di ketahui oleh masyarakat sebagai pengguna media komunikasi dalam bentuk jejaring sosial, yaitu:

1. Etika dalam berkomunikasi

2. Hindari penyebaran SARA, pornografi dan aksi kekerasan

3. Kroscek kebenaran berita

4. Menghargai hasil karya orang lain

\section{b. Komunikasi Pembangunan}

Komunikasi merupakan sebuah transmisi pesan baik itu pesan informatif, persuasive atau koesif. Seperti telah disinggung diatas komunikasi dapat dianggap sebagai transmisi informasi. Informasi merupakan suatu bentuk dan pola. Jadi dengan demikian bahwa pengiriman dan penerimaan bentuk dalam komunikasi (Silvana, 2017:25).

Komunikasi pembangunan merupakan proses interaksi seluruh warga masyarakat (aparat pemerintah, penyuluh, tokoh masyarakat, LSM, individu atau kelompok/organisasi sosial) untuk menumbuhkan kesadaran dan menggerakkan partisipasi melalui proses perubahan terencana demi tercapainya mutu-hidup secara berkesinambungan, dengan menggunakan teknologi atau menerapkan ide- ide yang sudah terpilih (Mardikanto, 1987:20). Komunikasi pembangunan meliputi peran dan fungsi komunikasi - sebagai suatu aktivitas pertukaran pesan secara timbal-balik - di antara semua pihak yang terlibat dalam usaha pembangunan; terutama antara masyarakat dengan pemerintah, sejak dari proses perencanaan, pelaksanaan dan penilaian terhadap pembangunan (Zulkarimen Nasution, 2002:106).

Dengan demikian dapat disarikan, bahwa komunikasi pembangunan adalah proses interaksi dan penyebaran informasi secara timbal balik antara pihak- pihak yang terlibat dalam usaha pembangunan (pemerintah, masyarakat, dan lembaga kemasyarakatan) sejak tahap perencanaan, pelaksanaan hingga penilaian pembangunan. Komunikasi pembangunan dilakukan untuk menumbuhkan kesadaran dan partisipasi masyarakat.

\section{c. Stakeholders dan Agen Pembangunan}


Komunikasi pembangunan melibatkan stakeholders pembangunan, yaitu semua individu, kelompok atau organisasi yang memiliki kepentingan, terlibat atau dipengaruhi (secara positif maupun negatif) oleh suatu kegiatan atau program pembangunan (Sumarto, 2004:18). Stakeholders pembangunan di level desa meliputi: pemerintahan desa, masyarakat dan lembaga kemasyarakatan (civil society). Ketiganya komponen tersebut merupakan pelaku komunikasi pembangunan di level desa, dan menjadi partner pemerintah daerah dalam pelaksanaan pembangunan prasarana pedesaan.

Pembangunan memerlukan adanya pihakpihak yang selalu mendorong ke arah perubahan (modernisasi). Menurut Teori Propencity of Change Lerner (Zulkarimen Nasution, 2002:108) modernisasi suatu bangsa ditandai terjadinya urbanisasi (urbanization). Urbanisasi akan meningkatkan melek huruf (literacy), lalu meningkatkan penggunaan media (media participation), berikut akan meningkatkan partisipasi politik masyarakat (political participation). Sehingga karakteristik masyarakat yang berpotensi menjadi agen-agen perubahan di lingkungannya dapat dilihat dari aspek urbanisasi, pendidikan, akses media dan partisipasi organisasi sosial politik.

Jenis penelitian yang dilakukan adalah penelitian deskriptif kualitatif. Penelitian kualitatif adalah penelitian yang bersifat deskriptif dan cenderung menggunakan analisis. Proses dan makna (perspektif subjek) lebih ditonjolkan dalam penelitian kualitatif. Landasan teori dimanfaatkan sebagai pemandu agar fokus penelitian sesuai dengan fakta di lapangan. Selain itu landasan teori ini juga bermanfaat untuk memberikan gambaran umum tentang latar penelitian dan sebagai bahan pembahasan hasil penelitian.

Kriyantono (2012) menyatakan bahwa, "Riset kualitatif bertujuan untuk menjelaskan fenomena dengan sedalam-dalamnya melalui pengumpulan data sedalam-dalamnya." Penelitian kualitatif menekankan pada kedalaman data yang didapatkan oleh peneliti. Semakin dalam dan detaild ata yang didapatkan, maka semakin baik kualitas dari penelitian kualitatif ini.

Penelitian ini, menggunakan teknik pemilihan informan yaitu purposive sampling. Purposive sampling adalah teknik pemilihan informan secara sengaja, peneliti menentukan sendiri informan yang diambil. Penentuan informan menggunakan teknik purposive ini memiliki kriteria tertentu salah satunya memilih informan yang dianggap kredibel untuk menjawab masalah penelitian.

\section{HASIL DAN PEMBAHASAN}

\section{a. Karakteristik masyarakat era digital}

Masalah yang muncul ke permukaan mengenai pemahaman masyarakat eradigital yakni mengenai sejauh mana definisi masyarakat era digital memperoleh porsiyang tepat dalam seluruh konteks perkembangan 
masyarakat secara luas. Pada dasarnya sebutan masyarakat era digital telah melekat dengan sendirinya pada situasi masyarakatyang telah ada. Merupakan suatu kenyataan bahwa setiap individu mempunyai kebutuhan dan tuntutan terhadap teknologi informasi. Perkembangan dinamika kemanusiaan menempatkan perkembangan teknologi informasi dalam konteks masyarakat era digital menjadi suatu kenyataan bahkan keharusan.

Indonesia hanya membutuhkan beberapa dekade saja pascakemerdekaan untuk menciptakan masyarakat era digital. Masyarakat era digital merupakan masyarakat yangmampu mengaplikasikan teknologi informasi ke dalam kesehariannya. Tanda yang signifikan dalam masyarakat era digital saat ini adalah perkembangan yang sangat cepatpada sektor ilmu pengetahuan dan teknologi. Tantangan era digital di Indonesiautamanya yakni bangsa Indonesia harus berusaha menyetarakan atau mengikuti perkembangan zaman akan perkembangan teknologi dunia, karena perkembanganteknologi dan informasi sangat pesat. Bangsa Indonesia harus meningkatkan kreatifitasnya dalam dunia teknologi agar dapat mengikuti perkembangan zaman yang sekarang ini dalam kondisi yang serba mutakhir. Hal ini tentu akan memberikan dampak yang sangat besar bagi dunia pendidikan khususnya terkait peluang dan tantangan kedepannya.

\section{b. Keterkaitan media komunikasi dengan pembangunan nasional}

Agar komunikasi pembangunan lebih berhasil mencapai sasarannya, serta dapat menghindarkan kemungkinan-kemungkinan efek yang tidak diinginkan, tentunya harus mempertimbangkan hal-hal. Kesenjangan efek yang ditimbulkan oleh kekeliruan cara-cara komunikasi selama ini, menurut Rogers dan Adhikarya (1978) dapat diperkecil bila strategi komunikasi pembangunan dirumuskan demikiaan rupa, mencakup prinsip-prinsip sebagai berikut:

1. Penggunaan pesan yang dirancang khusus (tailored messages) untuk khalayak yang spesifik. Misalnya, bila hendak menjangkau khalayak miskin pada perumusan pesan, tingkat bahasa, gaya penyajian, dan sebagainya, disusun begitu rupa agar dapat dimengerti dan serasi dengan kondisi mereka.

2. Pendekatan ceiling effect yaitu pendekatan dengan mengomunikasikan pesan- pesan yang bagi golongan yang tidak dituju, katakanlah golongan atas, merupakan "redundansi" (tidak lagi begitu berguna karena sudah dilampaui mereka) atau kecil manfaatnya, namun tetp berfaedah bagi golongan khalayak yang hendak dijangkau. Dengan cara ini, dimaksudkan, agar golongan khalayak yang benar-benar berkepentingan tersebut mempunyai kesempatan untuk mengejar 
ketertinggalanya, dan dengan demikian dapat mempersempit jarak efek komunikasi yang telah disinggung diatas tadi.

3. Penggunaan Pendekatan Narrow Casting atau melokalisasi penyampaian pesan bagi kepentingan khalayak. Lokalisasi disini berarti disesuaikannya penyampaian informasi yang dimaksud dengan situasi kesempatan dimana khalayak berada.

4. Pemanfaatan saluran tradisional, yaitu berbagai bentuk pertunjukan rakyat yang sejak lama memamg berfungsi sebagai saluran pesan yang akrab dengan masyarakat setempat.

5. Pengenalan para pemimpin opini dikalangan lapisan masyarakat yang berkekurangan (disadvantage), dan meminta bantuan mereka untuk menolong mengomunikasikan pesan-pesan pembangunan.

6. Mengaktifkan keikutsertaan agen-agen perubahan yang berasal dari kalangan masyarakat sendiri sebagai petugas lembaga pembangunan yang beroperasi dikalangan rekan sejawat mereka sendiri.

7. Diciptakan dan dibina cara-cara atau mekanisme bagi keikutsertaan khlayak, sebagai pelaku-pelaku pembangunan itu sendiri, dalam proses pembangunan yaitu sejak tahap perencanaan sampai evaluasinya.

Menurut Frank Dance (Syarif, Unde, \& Asrul, 2014), salah satu aspek penting di dalam komunikasi adalah konsep reduksi ketidakpastian. Komunikasi itu sendiri muncul karena adanya kebutuhan untuk mengurangi ketidakpastian, supaya dapat bertindak secara efektif demi melindungi atau memperkuat ego yang bersangkutan dalam berinteraksi secara individual maupun kelompok. Dalam penanganan bencana, informasi yang akurat diperlukan oleh masyarakat maupun sektor swasta yang memiliki kepedulian terhadap penanggulangan bencana

Komunikasi berperan penting dalam pembangunan. Apabila kita menengok ke belakang, sarana komunikasi di negara-negara berkembang yang dulunya masih terbatas pada media cetak, semuanya kini telah berubah. Teknologi komunikasi mulai berkembang pesat, terutama dengan adanya televisi, internet, dan telepon. Perkembangan ini menyebabkan "jarak psikologis" mendekatkan "jarak geografis" antar bangsa. Namun di sebagian negara sedang berkembang, masih terdapat ketimpangan informasi dalam sistem komunikasi mereka. Ketimpangan komunikasi tersebut dapat menimbulkan perbedaan persepsi tentang pembangunan, yang pada akhirnya menghambat pembangunan itu sendiri. 


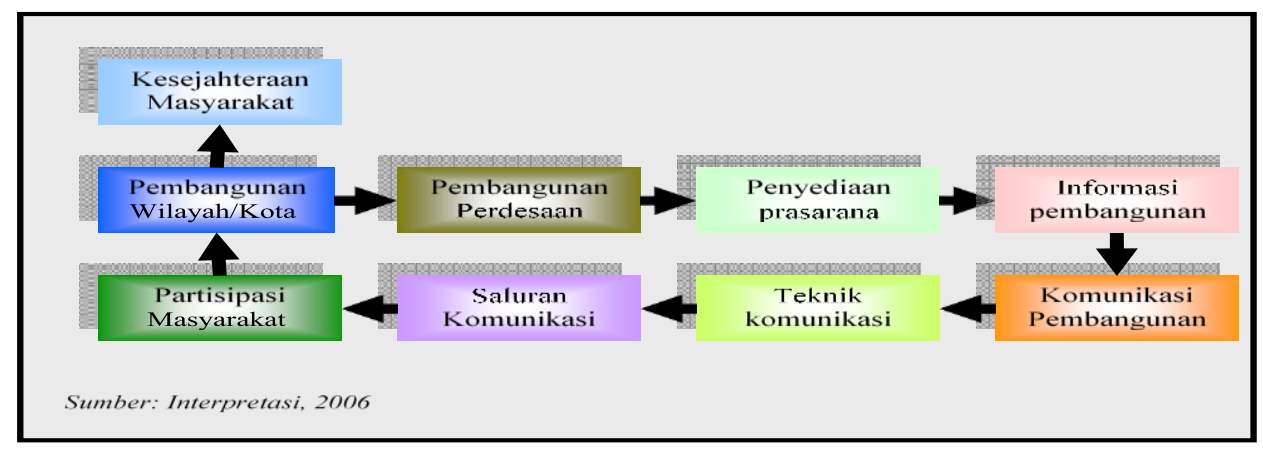

GAMBAR 1.

HUBUNGAN KOMUNIKASI DAN PEMBANGUNAN NASIONAL

Sumber : Hasil Penelitian Amir Mahmud, Undip 2007.

Hassan, seperti yang dikutip Jahi (1988: 111),menunjukkan bahwa ada tiga fungsi media massa dalam pembangunan, yaitu:

1. Memberi tahu rakyat tentang pembangunan nasional, memusatkan perhatian mereka pada kebutuhan untuk berubah, kesempatan untukmenimbulkan perubahan, metoda dan caramenimbulkan perubahan, dan jika mungkin meningkatkan aspirasi.

2. Membantu rakyat berpartisipasi dalam proses pembuatan keputusan, memperluas dialog danmenjaga agar informasi mengalir baik ke atasmaupun ke bawah.

3. Mendidik rakyat agar memiliki keterampilan. Ketiga fungsi media itu, sepadan dengan pendapat Chalkley yang dikutip Medis (dalam Jahi,1988: 112), tentang peranan media massa yang dapat diberikan dalam pembangunan model partisipatif, yaitu :

a) Memberi tahu masyarakat tentang faktakehidupan ekonomi mereka. b) Menginterpretasikan fakta tersebut agar dapat dipahami oleh masyarakat itu dan kemudian mempromosikan hal tersebut agar masyarakat menyadari betapa serius masalah pembangunan yang mereka hadapi dan memikirkan lebih lanjut masalah itu, serta menyadarkan mereka pada solusisolusi yang mungkin ditempuh.

c) Meskipun peranannya terbatas, komunikasi tidak boleh diperlakukan sekadar kegiatan penunjang pembangunan. Komunikasi harus dijadikan salah satu komponen pembangunan,sama seperti komponen-komponen lainnya, kalau tidak ingin mendapatkan kesulitan besar dikemudian hari.

\section{c. Peluang dan tantangan yang timbul pada masyarakat era digital}

Perkembangan teknologi yang begitu cepat hingga merasuk di seluruh lini kehidupan sosial masyarakat, ternyata bukan saja 
mengubah tatanan kehidupan sosial, budaya masyarakat tetapi juga kehidupan politik. Kecanggihan teknologi yang dikembangkan oleh manusia benar-benar dimanfaatkan oleh para politisi yang ingin meraih simpati, dan empati dari masyarakat luas. Untuk menaikan elektabilitas dan popularitas dapat dilakukan dengan fasilitas digital seperti salah menghubungkan dengan pelanggan, dan alatalat produktivitas. Tantangan dalam bidang teknologi informasi sangat banyak seperti memecahkan suatu masalah, membuka kreativitas, meningkatkan efektivitas dan efisiensi dalam melakukan pekerjaan.

Era digital telah membawa berbagai perubahan yang baik sebagai dampak positif yang bisa gunakan sebaik-baiknya. Namun dalam waktu yang bersamaan, era digital juga membawa banyak dampak negatif, sehingga menjadi tantangan baru dalam kehidupan manusia di era digital ini. Tantangan pada era digital telah pula masuk ke dalam berbagai bidang seperti politik, ekonomi, sosial budaya, pertahanan, keamanan, dan teknologi informasi itu sendiri.

Tantangan yang besar dihadapi oleh masyarakat saat ini adalah masyarakat kurang dapat mengendalikan diri atau mengontrol diri dalam penggunaan media komunikasi khususnya bentuk jejaring sosial. Banyak masyarakat yang mudah terpengaruh dan menyebarkan berita atau informasi yang belum jelas kebenarannya. Atau masyarakat menyebutnya hoax. Sehingga dalam hal ini etika pengunaan media komunikasi perlu di berikan melalui penyuluhan dari pihak - pihak yang terkait.

\section{d. Upaya Yang Harus di Lakukan pada Era Digital}

Era digital harus disikapi dengan serius,menguasai, dan mengendalikan peran teknologi dengan baik agar era digital membawa manfaat bagi kehidupan. Pendidikan harus menjadi media utama untuk memahami, mengusai, dan memperlakukan teknologi dengan baik dan benar. Anak-anak dan remaja harus difahamkan dengan era digital ini baik manfaat maupun madharatnya. Orang tua harus pula difahamkan agar dapat mengontrol sikap anak-anaknya terhadap teknologi dan memperlakukannya atau menggunakannya dengan baik dan benar.

Pengenalan tentang pemanfaatan berbagai aplikasi yang dapat membantu pekerjaan manusia perlu dikaji agar diketahui manfaat dan kegunaannya serta dapat memanfaatkannya secara efektif dan efisien terhindar dari dampak negatif dan berlebihan. Demikian juga pemerintah melakukan kajian mendalam era digital ini dalam berbagai bidang seperti politik, ekonomi, sosial budaya, pertahanan atau keamanan serta teknologi informasi.

Etika penggunaan media komunikasi dalam bentuk jejaring sosial dapat dilakukan dengan memberikan penyuluhan kepada 
masyarakat di setiap tempat/wilayah. Hal ini memiliki tujuan agar pembangunan nasional di indonesia dapat terlaksana dengan baik. Berikut etika yang harus diketahui oleh masyarakat luas dalam penggunaan media komunikasi yang baik untuk menyampaikan aspirasinya kepada pemerintah terkait pembangunan nasional.(Nugroh, 1997).

\section{e. Etika dalam Berkomunikasi}

Pada saat melakukan komunikasi dengan memanfaatkan media sosial, biasanya banyak yang cenderung melupakan etika dalam berkomunikasi. Hal ini di buktikan dengan banyaknya kata-kata kasar yang kerap kali muncul pada saat melakukan percakapan melalui jejaring sosial, baik yang sengaja dan tidak sengaja. Biasakanlah untuk menggunakan Bahasa yang tepat dengan siapapun pada saat kita berinteraksi, termasuk saat berinteraksi melalui media sosial.(Nugroh, 1997).

\section{f. Hindari Penyebaran SARA, Pornografi dan Aksi Kekerasan}

Alangkah baiknya apabila kita tidak menyebarkan informasi yang mengandung unsur SARA (Suku, Agama dan Ras) serta pornografi padajejaring sosial. Biasakan untuk menyebarkan hal-hal yang berguna dan tidak menimbulkan konflik antar sesama. Hindari juga mengupload foto kekerasan seperti foto korban kekerasan, foto kecelakaan lalu lintas maupun foto kekerasan dalam bentuk lainnya. Menurut Rahadi (Andu, 2018) mengatakan bahwa permasalahan yang timbul dari penggunaan media sosial adalah banyaknya informasi palsu atau hoax yang menyebar luas, bahkan orang terpelajar pun tidak bisa membedakan mana berita yang benar, advertorial, dan hoax.

\section{Kroscek Kebenaran Berita}

Saat ini tentu tidak jarang kalau kita menemukan berita yang menjelekan salah satu pihak dimedia sosial. Hal inilah yang terkadang bertujuan demi menjatuhkan nama pesaing dengan menyebarkan berita yang hasil rekayasa. Maka dari itu, pengguna media sosial dituntut agar lebih cerdas lagi saat menangkap sebuah informasi, apabila Anda ingin menyebarkan informasi tersebut, alangkah bijaknya jika Anda melakukan kroscek terlebih dahulu atas kebenaran informasi tersebut.

\section{Menghargai Hasil Karya Orang Lain}

Pada saat menyebarkan informasi baik dalam bentuk foto, tulisan maupun video milik orang lain maka biasakan untuk mencantumkan sumber informasi sebagai salah satu bentuk penghargaan atas hasil karya seseorang. Jangan membiasakan diri untuk serta merta mengcopypaste tanpa mencantumkan sumber informasi tersebut.

\section{PENUTUP}

Dari penelitian yang dilaksanakan maka dapat diambil kesimpulan bahwa, berdasarkan informasi yang diperoleh dalam kegiatan sehari-hari masyarakat secara umum telah 
menggunakan media sosial dan alat komunikasi yang ada untuk mendukung kegiatan ataupun pekerjaan mereka. Baik itu masyarakat umum maupun pelaksana kebijakan di daerah.

Dalam pelaksanaan pembangunan nasional dilihat dari SDM, tempat atau lingkungan masyarakat, dan taraf pendidikan. Maka dari itu, hendaknya pembangunan nasional yang mencakup SDM, tempat atau lingkungan masyarakat, dan taraf pendidikan dapat memprediksi sekaligus mengendalikan penggunaan media sosial maupun komunikasi yang berlebihan dan tidak beretika dengan baik.

Hal tersebut dapat terlaksana dengan baik apabila adanya suatu kerjasama antara masyarakat dengan pemerintah daerah setempat yaitu melalui penyuluhan terhadap masyarakat mengenai etika berkomunikasi dengan media komunikasi yang baik dan menyampaikan aspirasi serta persoalan yang terjadi di dalam masyarakat dengan cepat, benar dan dapat dipertanggung jawabkan kebenaranya. Dengan demikian cita-cita dalam pembangunan nasional dapat dilaksanakan sejalan dengan perkembangan komunikasi dan media sosial masyarakat yang berkembang.

\section{DAFTAR PUSTAKA}

A.M, M. (2010). Periklanan komunikasi pemasaran terpadu. Jakarta: Penerbit Kencana.
Andu, C. P. (2018). Efek Postingan Sara Di Media Sosial Terhadap Pertemanan Christine Purnamasari Andu Pendahuluan Media sosial merupakan sebuah wadah dimana setiap penggunanya dapat berinteraksi secara online. Penggunaan media sosial sangat beragam tergantung dari para pem. KRITIS : Jurnal Ilmu Sosial Dan Ilmu Politik, 4(1), 1-10.

Jahi, Amri (ed). 1988. Komunikasi Massa dan Pembangunan Pedesaan di Negara-negara Dunia ketiga. Jakarta. Gramedia.

Kriyantono. 2012.Public Relations. Jakarta : Erlangga.

Madcoms, \& Andi. (2010). Adobe Dreamweaver CS5 dengan Pemrograman PHPMySQL. Jakarta: CV Andi Offset.

Mardikanto, T. (1987). Komunikasi Pembangunan. Surakarta: Sebelas Maret University Press.

Morrisan. 2019. Teori Komunikasi:individu hingga massa. Jakarta: Kencana.

Nugroh, H. (1997). Dekonstruksi Wacana SARA Negara dan Implikasinya Terhadap Kemajemukan Masyarakat Indonesia. Jurnal Ilmu Sosial Dan Ilmu Politik Fakultas Ilmu Sosial Dan Ilmu Politik Universitas, 1(2).

Rogers, dan Adhikarya. 1978. Media dan Masyarakat Modern. Jakarta. Penerbit Kencana.

Silvana, Tine dan Rohanda (2017). Efektivitas Penggunaan Media Komunikasi Dalam 
Rangka Sosialisasi Program GPMB

(Gerakan pembinaan masyarakat baca) di Jawa Barat. Commed: Jurnal Komunikasi dan Media, 2(1), 25.

Syarif, A., Unde, A. A., \& Asrul, L. (2014). Pentingnya Komunikasi Dan Informasi pada Implementasi Kebijakan Penyelenggaran Penanggulangan bencana di kota makassar. Jurnal Komunikasi KAREBA, 3(3), 142-152.

Sumarto. 2004. Inovasi, Partisipasi dan Good Governance. Jakarta. Yayasan Obor Indonesia.
Ubaidillah, A. (2016). Konsep dasar komunikasi untuk kehidupan. Al-Ibtda', 4(2), 30-54.

Yuliani, F, Adriadi, R.,\& Safitra, L., (2020). Media Baru dalam Pelayanan Publik. Commed: Jurnal Komunikasi Dan Media, 4(2), 149.

Zulkarimen Nasution. (2002). Komunikasi Pembangunan: Pengenalan Teori dan Penerapannya. Jakarta: PT. Raja Grafindo Persada. 